\title{
Aplikasi Pembelajaran Kanak-Kanak Berbasis Web
}

\author{
Dewi Mustari \\ Staff Pengajar Teknik \\ Informatika Universitas \\ Indraprasta PGRI \\ Jl. Nangka No. 58E Tanjung \\ Barat, Jagakarsa, Jakarta \\ Selatan
}

\author{
Dewi Driyani \\ Staff Pengajar Teknik \\ Informatika Universitas \\ Indraprasta PGRI \\ J1. Nangka No. 58E Tanjung \\ Barat, Jagakarsa, Jakarta \\ Selatan
}

\author{
Han Sulaiman \\ Staff Pengajar Teknik \\ Informatika Universitas \\ Indraprasta PGRI \\ J1. Nangka No. 58E Tanjung \\ Barat, Jagakarsa, Jakarta \\ Selatan
}

\begin{abstract}
Abstrak- Penelitian ini merupakan penelitian lanjutan dari penelitian-penelitian sebelumnya. Penelitian sebelumnya membahas mengenai model pembelajaran, perancangan sistem sebelum mengimplentasikannya ke dalam aplikasi pembelejaran di taman kanak-kanak berbasis web. Untuk bisa diaplikasikan maka peneliti harus melanjutkan penelitian ini dengan mengimplentasikannya kedalam bahasa pemrograman. Proses pembelajaran merupakan salah satu proses pencerdasan bangsa dilakukan pemerintah untuk melayani masyarakat dengan berbagai cara, salah satunya dengan memanfaatkan teknologi informasi dan telekomunikasi. Perkembangan teknologi informasi dan telekomunikasi berkembang demikian pesat. Salah satu dampak yang sangat jelas dirasakan adalah dalam aktivitas pembelajaran. Guru sebagai salah satu bagian dari akademis, memiliki peranan penting dalam terciptanya budaya belajar yang terampil, praktis serta mampu mengikuti perubahan pasar. bahan pelajaran merupakan salah satu alat bagi kegiatan akademika untuk melakukan proses belajar mengajar. Oleh karena itu, peneliti akan membuat aplikasi pembelajaran yang bisa di akses oleh orang tua murid dan guru. maka dalam penelitian ini peneliti akan membuat aplikasi pembelajaran berbasis web mengunakan Knowledge Management System dengan mengaplikasikannya kedalam sebuah bahasa pemrograman sehingga akan mempermudah guru dalam mengelola data pembelajaran. Untuk mengaplikasikannya kedalam aplikasi pembelajaran, maka peneliti menggunakan bahasa pemrograman PHP. Dan hasilnya merupakan aplikasi sistem informasi pembelajaran untuk taman kanak-kanak berbasis web.
\end{abstract}

Kata kunci: Knowledge Management System, Sistem Informasi, PHP, Aplikasi pembelajaran.

\section{PENDAHULUAN}

Pendidikan anak usia dini merupakan upaya untuk menstimulasi, membimbing, mengasuh dan memberikan kegiatan pembelajaran yang mampu menghasilkan kemampuan dan keterampilan anak. Pendidikan anak usia dini merupakan suatu pendidikan yang dilakukan pada anak sejak lahir hingga usia delapan tahun.
Para ahli psikolog tersebut percaya bahwa ada empat unsur atau konsep dasar yang harus diperhatikan dalam menyelenggarakan pembelajaran untuk anak usia dini, yaitu teori pengetahuan (theory of knowledge), teori perkembangan (theory of development), teori belajar (theory of learning), dan teori mengajar (theory of teaching). Pada hakikatnya anak senang bermain, anak sangat menikmati permainan, tanpa terkecuali. Melalui bermain, anak dapat menyesuaikan diri dengan lingkungannya dan dapat menjadi lebih dewasa. (depdiknas, 2006)

Oleh karena itu dengan merancang metode pembelajaran dengan memanfaatkan perkembangnya teknologi maka dibuat Knowledge Management untuk proses belajar mengajar di Taman Kanak - kanak untuk membantu siswa mendapatkan informasi bahan pelajaran, serta memudahkan guru untuk berbagi informasi bahan pelajaran. Guru sebagai salah satu bagian dari akademis, memiliki peranan penting dalam terciptanya budaya belajar yang terampil, praktis serta mampu mengikuti perubahan pasar.

Bahan pelajaran merupakan salah satu alat bagi kegiatan akademika untuk melakukan proses belajar mengajar. Oleh karena itu, peneliti akan membuat aplikasi pembelajaran yang bisa di akses oleh orang tua murid dan guru. Berdasarkan uraian yang telah peneliti paparkan, maka dalam penelitian ini peneliti akan membuat aplikasi pembelajaran berbasis web mengunakan Knowledge Management System.

Maka dengan ini peneliti melakukan penelitian yang berjudul "Aplikasi pembelajaran Untuk Taman Kanak Kanak Berbasis Web"mendukung proses untuk mengambil atau menangkap knowledge, baik yang bersifat tacit maupun explicit, yang berada pada people, artifacts dan organizational entities.

"Sistem Informasi adalah suatu sisitem di dalam suatu organisasi yang mempertemukan kebutuhan pengolahan transaksi harian, mendukung operasi, bersufatmanajerial dan kegiatan strategi dari suatu organisasi dan menyediakan pihak luar tertentu dengan laporan-laporan yang diperlukan" (Jogianto. HM, 1999, hal:11). 
Sesungguhnya yang dimaksud dengan sistem informasi tidak harus melibatkan komputer bias disebut sistem informasi berbasis komputer (Computer-Based Information System atau CBIS). Dalam prakteknya, istilah sistem informasi lebih sering dipakai tanpa embel-embel berbasis komputer walaupun dalam kenyataannya komputer merupakan bagian yang penting.

Menurut Widodo, (2011:6), "UML adalah bahasa pemodelan standar yang memiliki sintak dan semantik". Menurut Nugroho (2010:6). "UML (Unified Modeling Language) adalah bahasa pemodelan untuk sistem atau perangkat lunak yang berparadigma (berorientasi objek)." Pemodelan (modeling) sesungguhnya digunakan untuk penyederhanaan permasalahanpermasalahan yang kompleks sedemikian rupa sehingga lebih mudah dipelajari dan dipahami.

Hypertext Preprocessor (PHP) adalah bahasa skrip yang dapat ditanamkan atau disisipkan ke dalam HTML. PHP banyak dipakai untuk memrogram situs

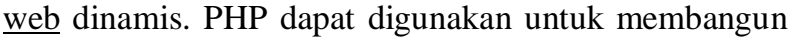
sebuah CMS. Pada awalnya PHP merupakan kependekan dari Personal Home Page (Situs personal). PHP pertama kali dibuat oleh Rasmus Lerdorf pada tahun 1995. Pada waktu itu PHP masih bernama Form Interpreted (FI), yang wujudnya berupa sekumpulan skrip yang digunakan untuk mengolah data formulir dari web.

Knowledge management system adalah integrasi antara teknologi dan mekanisme yang dibangun untuk mendukung proses knowledge management ${ }^{\text {[Bec-Fer 2004]. }}$

Ada beberapa jenis knowledge management system, yakni knowledge discovery systems, knowledge capture systems, knowledge sharing system dan knowledge application systems.

\section{METODE PENELITIAN}

Jenis penelitian ini adalah studi kasus dengan pendekatan kualitatif.pendekatan kualitatif menekankan pada makna, penalaran, definisi suatu situasi tertentu, lebih banyak meneliti hal - hal yang berhubungan dengan kehidupan sehari - hari.

Dalam pemilihan sampel, pengambilan data dari populasi yang terbatas (limit population) dengan menggunakan purposive sampling, yaitu pengambilan sampel dilakukan atas dasar pertimbangan tertentu(Jogiyanto, 2005). Berdasarkan penelitian sebelumnya Responden yang diambil dalam pemilihan adalah guru yang berasal dari TK PGRI Kota Banjar. Sehingga setalah mendapatkan data dari responden maka peneliti bisa mengumpulakan data yang di butuhkan untuk membuat aplikasi pembelajaran.

Pengumpulan data merupakan bagian paling penting dalam sebuah penelitian yang bertujuan untuk mendapatkan informasi dan datayang berhubungan dengan penelitian.Ketersediaan data akan sangat menentukan dalam proses pengolahan dan analisa selanjutnya. Untuk mengumpulkan data dan informasi tersebut, dilakukan dengan 2 metode pengumpulan data yaitu pengumpulan data primer dan pengumpulan data sekunder.

Teknik analisa data dalam penelitian ini, mengunakan metode terstruktur akan diimplementasikan dalam sebuah aplikasi pembelajaran berbasis web. Teknik analisis yang digunakan pada penelitian ini menggunakan pendekatan terstruktur. Proses analisis dilakukan terhadap hasil tahapan pengumpulan data dengan wawancara, observasi, dan studi pustaka untuk mendapatkan spesifikasi kebutuhan sistem.

Teknik perancangan sistem yang digunakan pada penelitian ini menggunakan Perancangan berorientasi objek menggunakan Unifield Modeling Languange ( UML )

\section{HASIL DAN PEMBAHASAN}

\section{A. Use case Diagram}

Rancangan sistem untuk aplikasi pembelajaran menggunakan Use Case Diagram yang diagmbar pada gamar 1 dibawah ini:

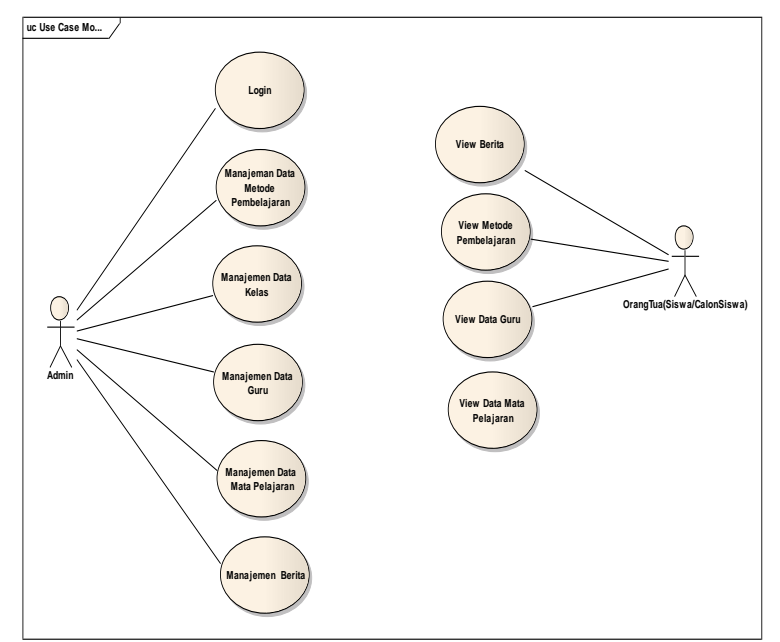

Gambar 1 Use Case Diagram

Pada gambar 1 uses case diatas, admin memiliki hak akses penuh terhadap sistem. Hak akses admin meliputi: manajemen data metode pengajaran, menejeman data kelas, manajemen data guru, manajemen data mata kuliah, dan manajemen berita. Sedangkan hak akses untuk orang tua (orang tua siswa/calon siswa) meliputi: view berita, view metode pengajaran, view data guru, dan view mata pelajaran yang diajarkan di Taman Kanak - Kanak PGRI Pataruman Banjar.

\section{B. Entity Relationship Diagram}




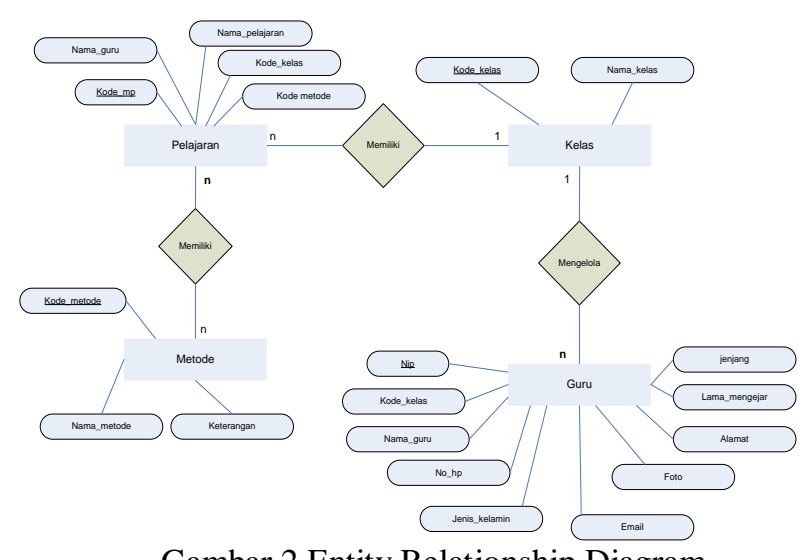

Gambar 2 Entity Relationship Diagram

Gambar 2 menjelaskan hubungan antara table yang berelasi, table pelajaran yang berelasi dengan table metode dan juga kelas, sedangkan table kelas berelasi dengan table guru, sehingga semua table saling berhubungan satu sama lain.

\section{Relasi Tabel}
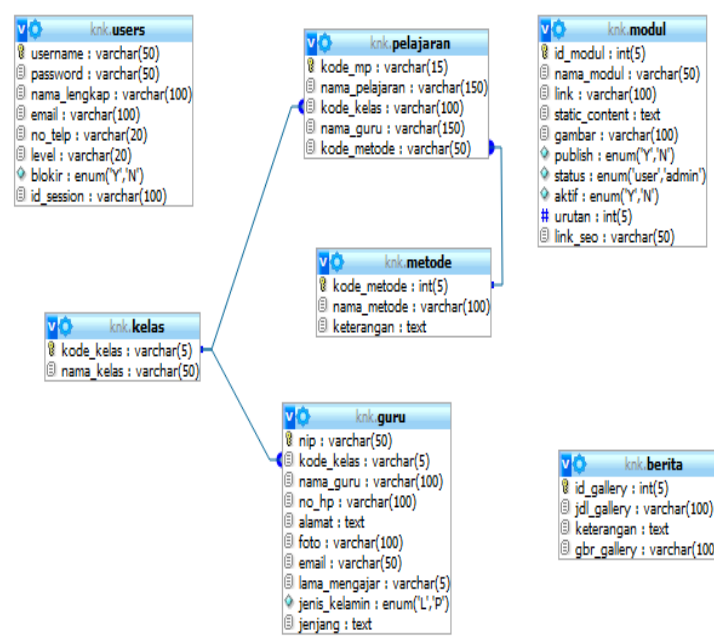

Gambar 3 Relasi Tabel pada Mysql

Gambar 3 menggambarkan semua table yang berada pada database taman kanak - kanak yang terdiri tujuh table, yang merupakan table inti terhubung satu sama lain yaitu table pelajaran, table metode, table kelas dan table guru sedangkan table user, modeul dan berita berdiri sendiri.

\section{Implementasi Program \\ 1). Tampilan Login Admin}

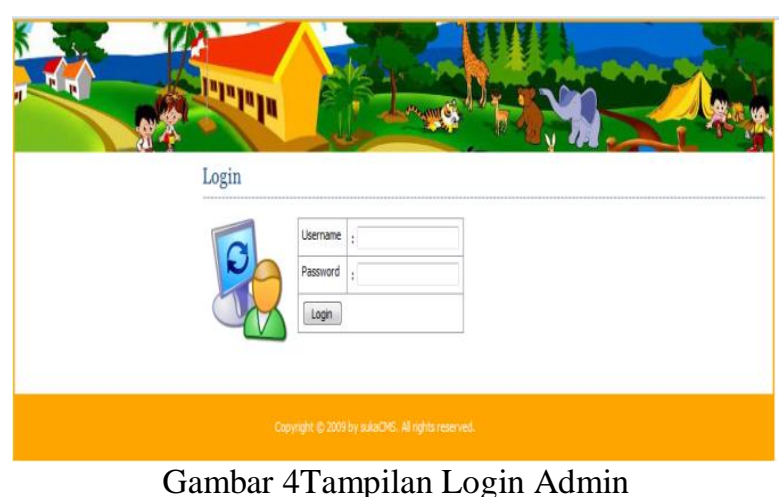

Gambar 4 yaitu gambar tampilan login. Pada saat user akan masuk ke program maka harus mengisi username dan password.

\section{2). Tampilan Menu Admin}

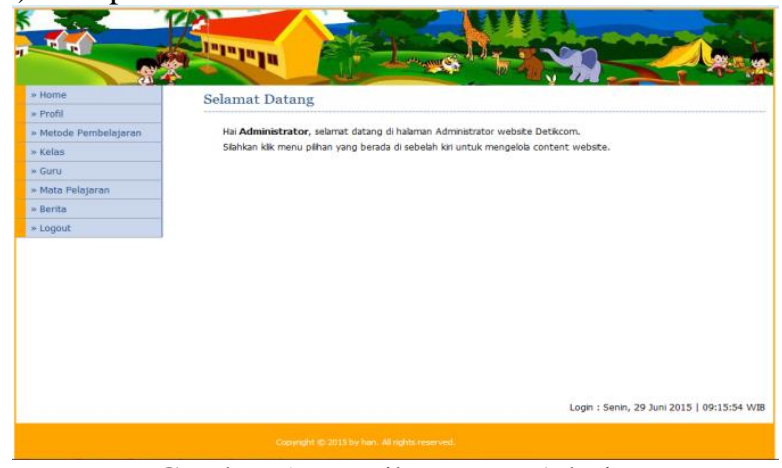

Gambar 5 Tampilan Menu Admin

Gambar 5 yaitu tampilan menu admin. Pada menu admin terdapat menu profile, metode pengajaran, kelas, guru, mata pelajaran, berita dan logout. Menu tersebut merupakan menu utama admin yang berfungsi untuk mengelola data yang berhubungan dengan data pembalajaran.

3). Tampilan Profile

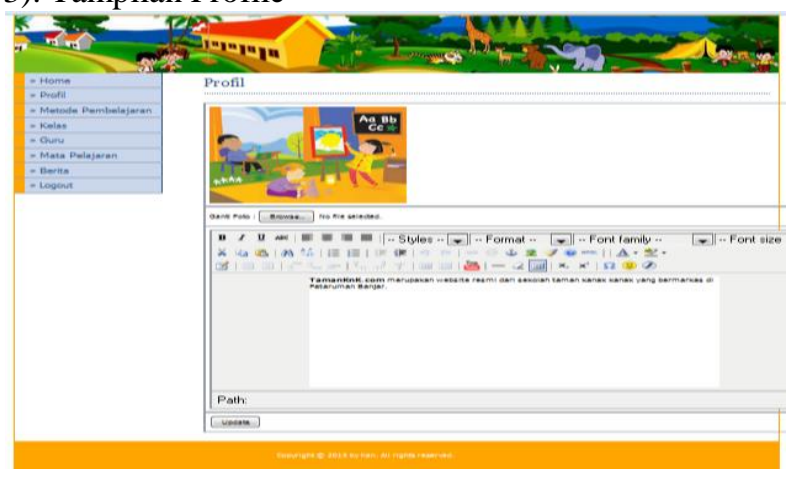

Gambar 6 Tampilan Profile

Gambar 6 yaitu tampilan untuk mengelola data profile sekolah. Dimana admin dapat mengubah gambar ataupun selogan mengenai sekolah taman kanak kanak PGRI Pataruman Banjar.

4). Tampilan Manajemen Data Metode Pembelajaran 


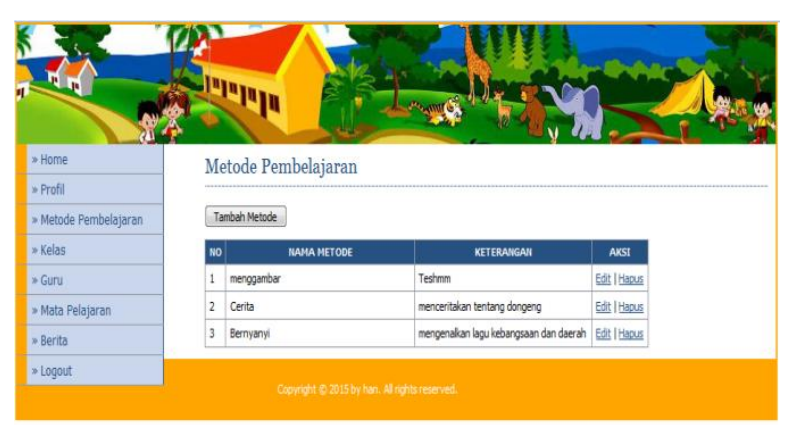

Gambar 7 Tampilan Manajemen Data Metode Pembelajaran

Gambar 7 yaitu tampilan admin pengelolaan data metode pengajaran, dimana admin dapat menambah, mengedit dan menghapus data metode pengajaran.

5). Tampilan Manajemen Data Kelas

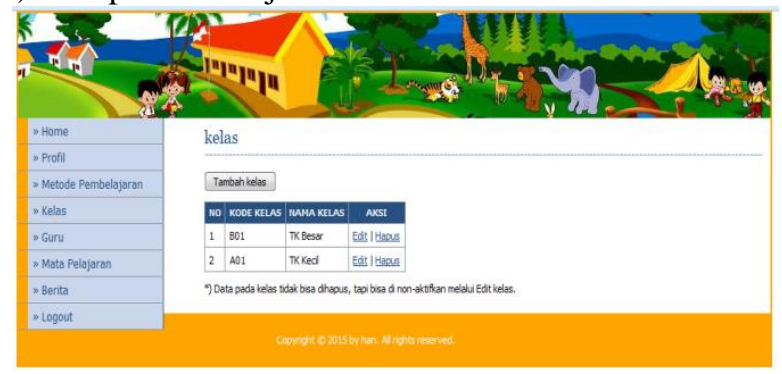

Gambar 8 Tampilan Manajemen Data Kelas

Gambar 8 yaitu tampilan admin pengelolaan data kelas, dimana admin dapat menambah, mengedit dan menghapus data kelas.

\section{6). Tampilan Manajemen Data Guru}

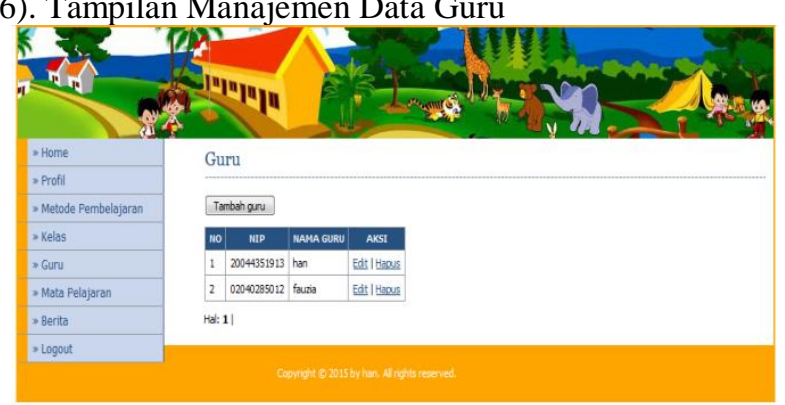

Gambar 9 Tampilan Manajemen Data Guru

Gambar 9 yaitu tampilan admin pengelolaan data guru, dimana admin dapat menambah, mengedit dan menghapus data guru yang mengajar di Taman kanak kanak PGRI Pataruman Banjar.

\section{7). Tampilan Manajemen Data Mata Pelajaran}

[PAUD 2006]. Pedoman Penerapan Pendekatan "Beyond Centers and Circle Time"(BCCT) Dalam Pendidikan Anak Usia Dini. Jakarta : Direktorat PAUD,Ditjen Pendidikan Luar Sekolah, Depdiknas

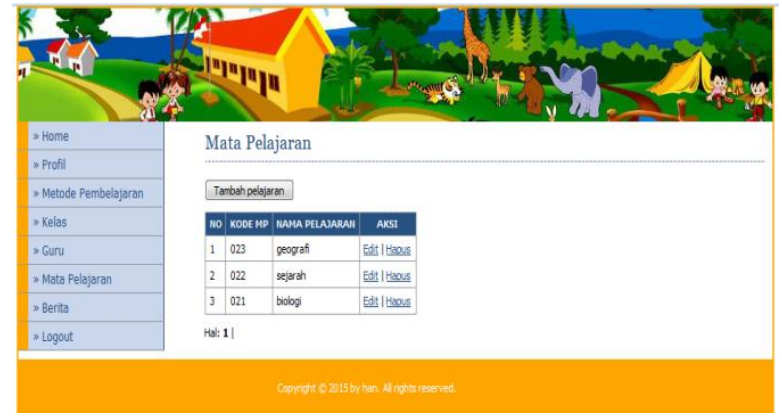

Gambar 10 Tampilan Manajemen Data Mata Pelajaran

Gambar 10 yaitu tampilan admin pengelolaan data mata pelajaran, dimana admin dapat menambah, mengedit dan menghapus data mata pelajaran yang diajarkan di Taman kanak - kanak PGRI Pataruman Banjar.

8). Tampilan Manajemen Data Berita

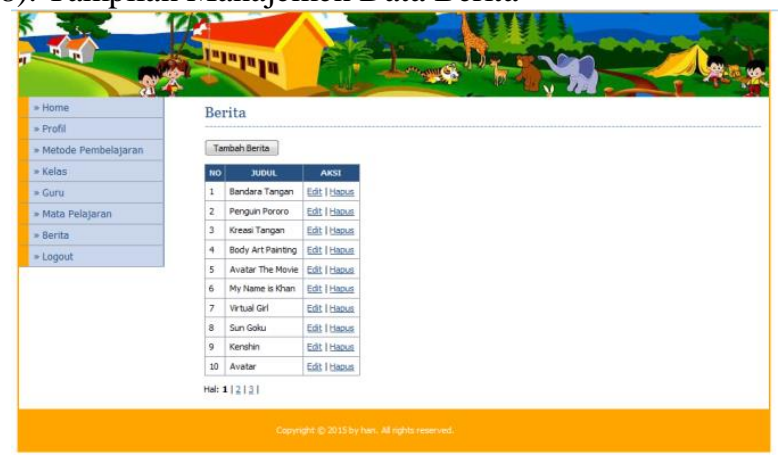

Gambar 11 Tampilan Manajemen Data Berita

Gambar 11 yaitu tampilan admin pengelolaan data berita, dimana admin dapat menambah, mengedit dan menghapus data berita yang merupakan informasi bagi guru dan orang tua murud Taman kanak - kanak PGRI Pataruman Banjar.

\section{KESIMPULAN}

Dari hasil pembahasan yang sudah di lakukan diperoleh beberapa kesimpulan, Yaitu :

- Dengan adanya aplikasi sistem informasi pembelajaran dapat mempermudah dalam menyimpan data bahan ajar, dan juga sebagai tempat promosi sekolah ke dunia luar.

- Dengan aplikasi sistem informasi pembelajaran ini, orang tua siswa bisa dengan mudah mendapatkan informasi mengenai bahan ajar dan guru data guru yang mengajar.

\section{REFERENSI}

[Bec-Fer 2004] Becerra-Fernandez, Irma, Gonzales, et.al, Rajiv,Knowledge Management: Challenges, Solutions and Technologies, Pearson/Prentice Hall, 2004. 
[Tobing 2007] Paul, L Tobing. Knowladge Managemen, Konsep, Arsitektur dan Implementasi. Yogyakarta : Graha Ilmu, 2007.

[sujiono, 2009] Sujiono, Yuliani Nurani. 2009. Konsep Dasar Pendidikan Anak Usia Dini, Jakarta: Indeks

[Susanto 2013] Susanto, Arif. Prototipe Sistem E Learning Berbasisi Knowladge Management : Studi Kasusu Paud Nur Rahma Tanjung, Tesis, Jakarta : Universitas Budi Luhur. 2013

[Ningky, 2001] Ningky. 2001. Proses Penciptaan Pengetahuan di perusahaan. Jakarta: Seminar Ikatan Pustakawan Indonesia
[Susanto 2013] Susanto, Arif. Prototipe Sistem E Learning Berbasisi Knowladge Management : Studi Kasusu Paud Nur Rahma Tanjung, Tesis, Jakarta : Universitas Budi Luhur. 2013

[Prabowo Pudjo Widodo. 2011]. "Menggunakan UML". Informatika. Bandung.

[Nugroho, Adi. 2010] . "Rekayasa Perangkat Lunak Menggunakan UML \& Java". Yogyakarta: Andi Offset.

[Henderi, Warsito. Ary Budi, Sidik. Ahmad. 2010]."Digital Library Modelling: Supporting For Knowledge Management". Perguruan Tinggi Raharja, Indonesia. 